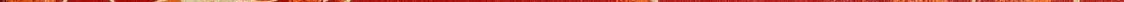





\section{Historic, archived document}

Do not assume content reflects current scientific knowledge, policies, or practices. 


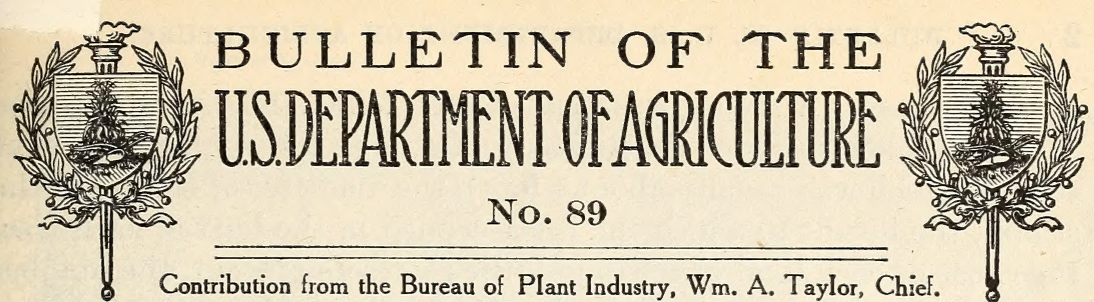

Contribution from the Bureau of Plant Industry, Wm. A. Taylor, Chief.

May 22, 1914.

(PROFESSIONAL PAPER.)

\title{
THE DEATH OF CHESTNUTS AND OAKS DUE TO ARMILLARIA MELLEA.
}

\author{
By W. H. Long, \\ Forest Pathologist, Office of Investigations in Forest Pathology.
}

\section{INTRODUCTION.}

Some time ago complaint was made to the Office of Investigations in Forest Pathology that the chestnut trees on certain areas near New Berlin, in Chenango County, N. Y., were rapidly deteriorating; that some were dead, others dying, and the remainder in poor health. Since this region is not in the known range of the chestnut bark disease (Endothia parasitica), the dying of the chestnut could not be attributed to this fungus, and the writer was therefore detailed to make an investigation of the trouble.

\section{CHARACTER OF THE TIMBER EXAMINED.}

Two areas of woodland of about 20 acres each were examined. The timber consisted of a mixed stand of chestnut, oak, and white pine, with a sprinkling of poplar, maple, and hemlock. All of the timber above a diameter of 6 inches, or even less, was being cut. Much of it had only recently been felled, while some was still uncut. The oak and chestnut were being made into railroad ties and the pine into lumber. Both tracts of timber were located on the level tops and slopes of rather rough ridges. The average age of the chestnut and oak was from 60 to 100 years. One of the areas had been partially logged over 20 years ago; the other had never been logged. There have been no forest fires in either tract, so far as known. As the two areas were close to each other and similarly located, they will be treated as a whole in this discussion.

\section{CHARACTER OF DATA OBTAINED.}

In addition to the felled trees of chestnut and oak, dead, dying, and badly diseased standing trees were studied. No attempt was made, on account of limited time, to examine the roots of any number

Note.-A record of the results of field investigations of the condition of chestnut and oak in Chenango County, N. Y.

$34907^{\bullet}-14-1$ 
of living trees. A record was kept of each felled and each dead tree. The data taken included the diameter of stump, the average height of stump (which was usually about 1 foot), the diameter of the rot in the stump, the height to which the rot ascended in the butt of each tree, the cause of each kind of rot found, the root-rots present, the number of dead trees, the cause of death, the number of dead trees blown down, and any other facts bearing on the health of the trees. Data on 902 felled trees were obtained. Of this number, 477 were white oaks, 302 chestnuts, 61 red oaks, 45 poplars, and the remainder maples, service berries, and pines.

\section{GENERAL CONDITION OF THE CHESTNUT.}

\section{HEALTH OF THE TREES.}

All of the chestnut trees over 18 inches in diameter were found to have diseased tops; that is, some were "stag headed," while all had one or more large dead branches on them. Many of the larger chestnut trees, especially those somewhat isolated on the edges of the ridges, had been struck by lightning. These trees were not killed outright, but in many cases tops, branches, and strips of bark of varying sizes had been killed. In a few instances the bark had been partially stripped from the tree, but usually the lightning left little or no external evidence of immediate injury. A careful examination, however, showed that wide strips of bark had been killed, especially near the bases of the trees, and that little or no callus had formed around the wounds. In the majority of cases the wounds had not healed, but were gradually increasing in size. This increase was always greater at the base of the tree and could usually be traced directly to the parasitic action of the fungus Armitlaria mellea. The typical rhizomorphs, or "shoe strings," of this fungus were present at the bases of the trees and extended 5 to 20 feet upward beneath the bark.

Of the tops, 75 per cent were infected by a pocketed or piped rot (Pl. I, fig. 1) caused by the fungus Polyporus pilotae, which had apparently entered through the old dead branches so common on the upper parts of chestnut trees in this region. In addition to this top-rot, 46 per cent of the felled trees were infected with butt-rot, the bulk of which was also caused by Polyporus pilotae.

\section{RATE OF GROWTH.}

The chestnut bark disease was not found in the region examined, but the chestnut trees, and also the oaks and poplars, were undoubtedly dying here and there from other causes. The annual rings in the chestnuts show that these trees had made a fairly rapid and vigorous growth during the first 20 or 30 years; then came a period of much slower growth, culminating in a period in which the annual 


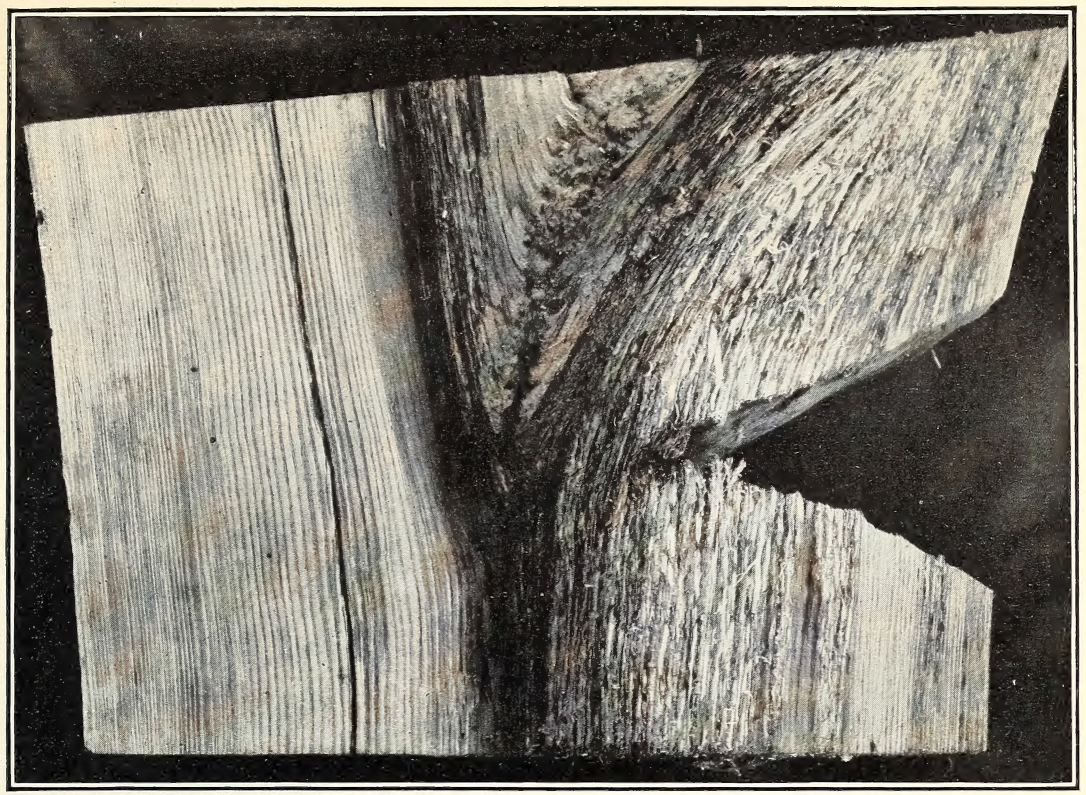

Fig. 1.-Heart-Rot in Chestnut Caused by Polyporus Pilotae.

The fungus entered at the dead branch and has moved downward into the heartwood of the tree proper.

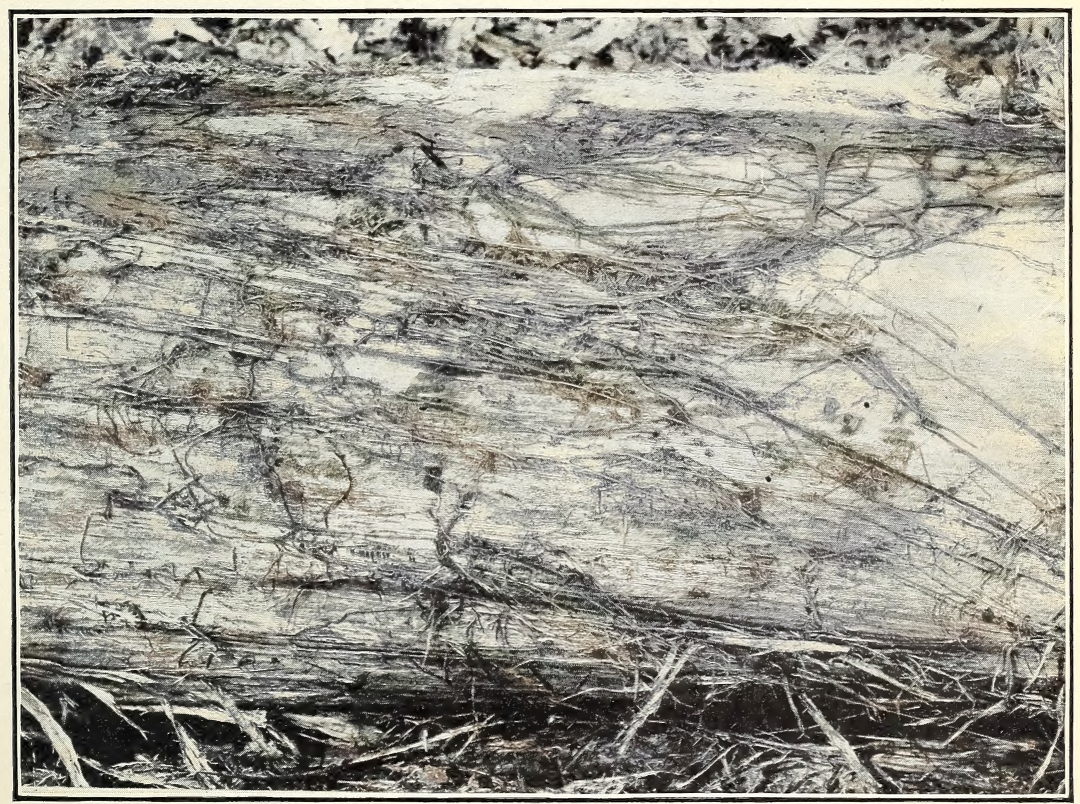

Fig. 2.- "Shoe Strings" of Armillaria Mellea beneath the Bark of a Felled CHESTNUT WHICH HAD BEEN KILLED BY THIS FUNGUS. 


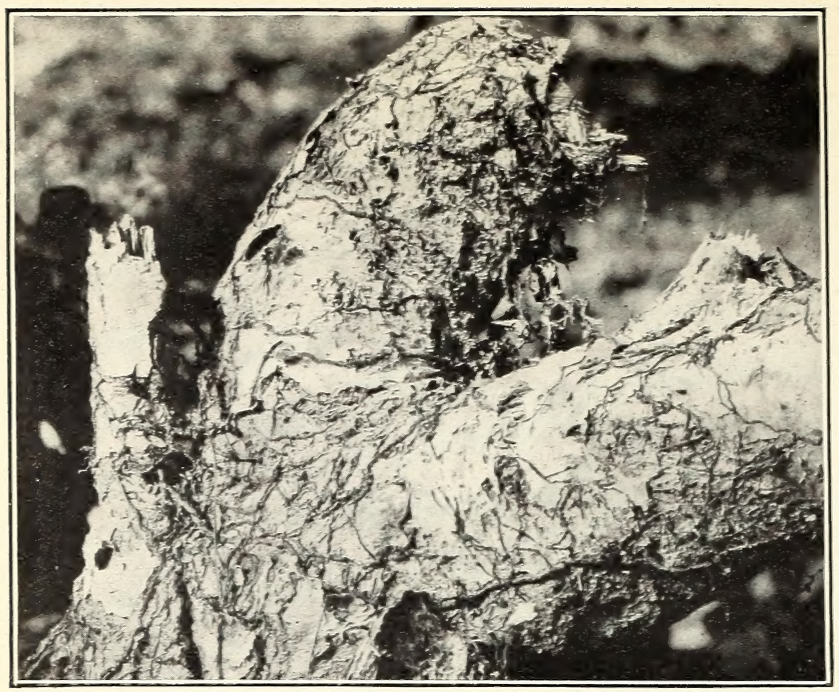

Fig. 1.- "Shoe Strings" of Armillaria Mellea on the Dead ROOTS OF A WIND-THROWN WHITE OAK.

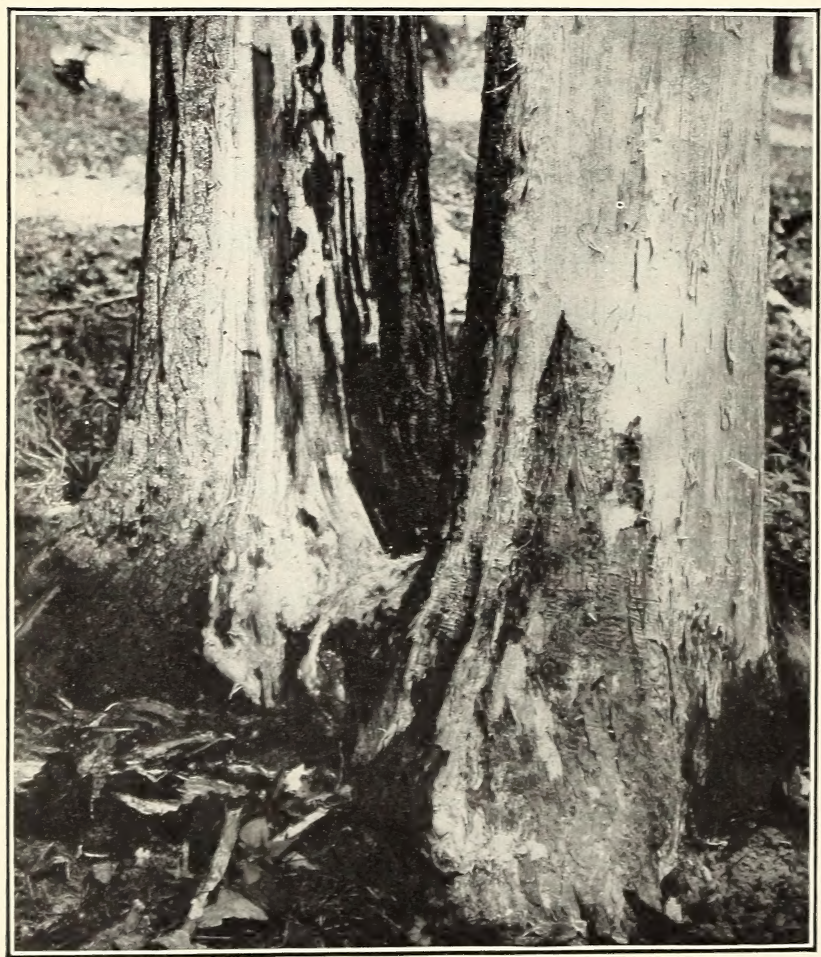

Fig. 2.-ARMillaria Mellea under the Bark of Two Chestnut TREES WHICH ARE JOINED AT THE GROUND.

The fungus has killed the tree in the foreground and has passed over to the other tree, where it has killed the bark for a distance of 8 feet upward and about one-third of the distance around the base of the tree. 
increment was less than 1 millimeter in radius. In those trees which had been killed the annual increment in radius for the last 6 to 10 years of their life was only one-third to one-fourth of a millimeter. The average rate of increment was found to be 25 millimeters in diameter for $7 \frac{1}{2}$ years of growth. This small increment indicates that the chestnut in this region is growing under very unfavorable conditions.

A clearer idea of how slowly these chestnuts have grown can be obtained by comparing the diameters of a few of these trees with those of chestnuts grown under more favorable conditions in other localities. For this purpose data are used which were published in 1905 by the Bureau of Forestry in Bulletin 53, entitled "The Chestnut in Southern Maryland," by Raphael Zon. The Forest Service has permitted the writer to use some unpublished data consisting of growth-diameter measurements made in West Virginia and Tennessee by Walter Mulford in 1905-6 and in Hyde Park, Dutchess County, N. Y., by J. G. Peters in 1905. The data from Hyde Park, where the growth conditions for chestnuts were favorable, are especially valuable for comparing with the growth data of chestnuts in New Berlin, as the two localities are in the same State. The growth data of chestnuts grown in Connecticut, included in Table I, were obtained by compiling the figures contained in Bulletin 154 of the Connecticut Agricultural Experiment Station, entitled "Chestnut in Connecticut and the Improvement of the Woodlot," by Austin F. Hawes.

TABLE I.-Diameter measurements and average ages of chestnut trees.

Diameter, Breast High (Inches).

\begin{tabular}{|c|c|c|c|c|c|c|}
\hline \multirow{2}{*}{ Age and diameter. } & \multicolumn{2}{|c|}{ New York. } & \multirow{2}{*}{$\begin{array}{l}\text { Connecti- } \\
\text { cut. }\end{array}$} & \multirow{2}{*}{$\begin{array}{l}\text { Mary- } \\
\text { land. }\end{array}$} & \multirow{2}{*}{$\begin{array}{l}\text { Tennes- } \\
\text { see. }\end{array}$} & \multirow{2}{*}{$\begin{array}{c}\text { West } \\
\text { Virginia. }\end{array}$} \\
\hline & $\begin{array}{c}\text { New } \\
\text { Berlin. }\end{array}$ & $\begin{array}{l}\text { Hyde } \\
\text { Park. }\end{array}$ & & & & \\
\hline $\begin{array}{r}\text { Age (years): } \\
10 \ldots \ldots \\
20 \ldots \ldots \\
30 . \ldots \ldots \\
40 \ldots \ldots \\
50 \ldots \ldots \\
60 \ldots \ldots \\
70 \ldots \ldots \\
80 \ldots \ldots \\
90 \ldots \ldots \\
100 \ldots \ldots \\
110 \ldots \ldots \\
\end{array}$ & $\begin{array}{r}1.6 \\
3.7 \\
5.7 \\
7.6 \\
8.3 \\
9.5 \\
10.7 \\
11.9 \\
12.0 \\
11.2 \\
11.3\end{array}$ & $\begin{array}{r}2.5 \\
4.9 \\
7.2 \\
9.4 \\
11.4 \\
12.9 \\
14.0 \\
\hdashline \\
\hdashline \ldots .\end{array}$ & $\begin{array}{r}3.4 \\
6.4 \\
9.5 \\
12.6 \\
15.6 \\
18.7 \\
21.7 \\
24.8 \\
27.8 \\
30.8\end{array}$ & $\begin{array}{r}3.75 \\
6.67 \\
9.25 \\
11.5 \\
13.4 \\
15.2 \\
17.3 \\
18.1 \\
19.1 \\
20.0 \\
\ldots . \ldots\end{array}$ & $\begin{array}{r}0.7 \\
3.1 \\
5.6 \\
8.2 \\
11.2 \\
13.7 \\
16.0 \\
18.4 \\
20.3 \\
21.7 \\
22.7\end{array}$ & $\begin{array}{r}0.5 \\
2.4 \\
4.3 \\
6.4 \\
8.4 \\
10.4 \\
12.5 \\
14.4 \\
16.3 \\
18.2 \\
19.9\end{array}$ \\
\hline
\end{tabular}

AGE (YEARS).

\begin{tabular}{|c|c|c|c|c|c|c|}
\hline 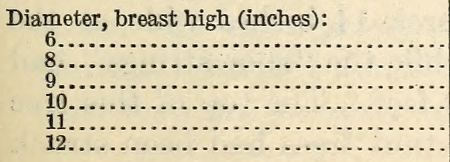 & $\begin{array}{l}32 \\
46 \\
56 \\
65 \\
80 \\
90\end{array}$ & $\begin{array}{l}25 \\
31 \\
38 \\
43 \\
47 \\
54\end{array}$ & $\begin{array}{l}29 \\
35 \\
39 \\
42 \\
45 \\
48\end{array}$ & $\begin{array}{l}17 \\
25 \\
29 \\
33 \\
38 \\
43\end{array}$ & $\begin{array}{l}32 \\
39 \\
44 \\
46 \\
49 \\
53\end{array}$ & $\begin{array}{l}38 \\
48 \\
53 \\
59 \\
63 \\
67\end{array}$ \\
\hline
\end{tabular}


From Table I it is readily seen that the chestnut at New Berlin, N. Y., has made a much slower growth than the trees from any of the other localities listed.

\section{GENERAL CONDITION OF THE WHITE OAK.}

Of the oaks in this region, the white oak (Quercus alba) predominates, but is intermixed with the red oak (Q. rubra). The tops of all the oaks appeared healthy, no "stag heads" or large dead branches being present. There was very little butt-rot of any kind in the boles. This was especially true of the area that had never been logged. In this area there occurred only 5 per cent of butt-rot and no top-rot of any kind. On the area which had been partially logged once there was a greater percentage of butt-rot due to injury to the standing timber from bruises on the roots and butts of the trees exposed to injury in logging. On this area the oak had 21 per cent of butt-rot, as against 5 per cent on the unlogged tract. Of this butt-rot, 87 per cent was caused by Hydnum erinaceus, which by decay makes hollows and is capable of entering through slight bruises on the trees, as well as through fire scars and other deep wounds.

\section{ARMillaria MELlEA ON CHESTNUTS, OAKS, AND POPLARS.}

The "shoe strings" of Armitlaria mellea were found very abundantly on the roots and under the bark of the butts of chestnuts, oaks, and poplars. They were also occasionally found on maples and on service berries (Amelanchier sp.), but none were found on the white pine. These "shoe strings" were also common in the soil around the bases of the diseased and dead trees. On some of the dead chestnut trees these "shoe strings" had grown upward under the bark for 15 or 20 feet. In many instances they had made a perfect network of strings over the sapwood (Pl. I, fig. 2). There could be no reasonable doubt that this fungus was killing the chestnut and oak, since trees were found in all stages of decline when it was present. Wherever a dead piece of bark on the base of a tree was removed, the brown or black rhizomorphs of this parasite were found beneath it. In such cases a watery zone of dying bark of a dark-brown color marked the boundary line between sound and diseased tissue. Sometimes only a very small area of the bark was affected, although the roots on this side of the tree were already dead and the outer layers of the sapwood were more or less decayed. The rotten sapwood is watery, white in color, soft, and easily broken. On a chestnut tree 18 inches in diameter this fungus had killed an area 14 inches wide at the ground and extending 15 feet upward, while the "shoe strings" had grown up under the bark a distance of 8 feet. The top of this tree was dead. In three instances where chestnut trees had been struck 
by lightning this disease was found following up and enlarging the wounds. Many of the white oaks killed by this fungus had been blown down. In every case the upturned roots were covered with a network of the black rhizomorphs (Pl. II, fig. 1). Several groups of two to four chestnut trees which had originated from sprouts around a common stump rere found killed by this root-rot. Plate II, figure 2 , shows two trees rom a common base, one being already dead and the other badly diseased. In the latter the bark and roots on the side adjacent to the dead tree were killed for about one-third of the distance around the base, and the rot had extended up the tree 8 feet ander the bark.

\section{PERCENTAge AND SIZE OF CHESTNUTS KILled By ARMILlaRia MELlEA.}

Of the 302 felled chestnut trees examined, 64, or 21 per cent, had becn killed by the Armillaria root-rot. The average diameter of these killed trees was 12 inches; the largest chestnut killed was 26 inches and the smallest 3 inches in diameter. Trees of all diameters between these limits were found diseased and killed. Of these trees, 10 had a diameter of 3 to 5 inches, 13 of 6 to 10 inches, 22 of 11 to 15 inches, and 19 of 16 to 26 inches. From this it follows that a greater percentage of the large chestnut trees was killed by this rootrot than of the smaller and younger trees. Of the 64 chestnut trees killed, 41, or 64 per cent, were over 10 inches in diameter. The average diameter of these 41 trees was 16 inches. In the white oak, just the reverse occurred; a greater percentage of the smaller and younger trees was killed than of the larger and older ones.

\section{PERCENTAGE AND SIZE OF OAKS KILLED BY ARMILLARIA MELLEA.}

Of the 477 oaks checked, 130, or 27 per cent, had been killed by the Armillaria root-rot. The average diameter of these killed trees was 7 inches, as compared with 12 inches in the chestnut. The largest oak killed was 18 inches and the smallest 2 inches in diameter. Trees of all sizes between these two extremes were affected. Of these white oaks, 39 ranged in diameter from 2 to 5 inches, 70 from 6 to 10 inches, and 20 from 11 to 15 inches, with only 1 over 15 inches. Of these 130 white oaks which had been killed, 84 per cent were less than 11 inches in diameter and only 16 per cent were over 10 inches in diameter, as compared with 64 per cent in the case of the dead chestnut trees in the same locality.

Of the white oaks killed by this root-rot, 46 had been overthrown by the wind, while only 2 of the dead chestnuts had been blown down. Of the wind-thrown oaks, 26 were from 6 to 8 inches in diameter, showing that the smaller as well as the larger sizes of white oaks were not as easily uprooted as those of medium diameter. 


\section{NUMBER AND SIZE OF POPLAR TREES KILLED BY ARMILLARIA MELLEA.}

In addition to the dead chestnuts and oaks, the writer counted 29 poplar trees which had been killed by this root-rot out of a total of 45 examined. Many of these were small and much suppressed, although there were 12 that ranged from 6 to 9 inches in diameter. These larger poplars were not suppressed and under normal conditions ought not to have died.

\section{GENERAL DISCUSSION OF THE DISEASED CHESTNUTS AND OAKS.}

Why a larger percentage of small white oaks should be killed than of small chestnut trees is difficult to explain from the data at hand. However, it seems to be evident, judging from the location of the smaller white oaks which were killed, that the majority of the trees under 11 inches in diameter were much suppressed and for this reason would perhaps succumb more quickly to disease than trees growing under more favorable conditions. Nothing was found to indicate that the larger white oaks which had been killed were in poor health before they were attacked by this disease. It would seem that the disease, having gained a foothold in the soil, simply spread to the large white oaks and finally killed them. As far as could be determined, the fungus Armillaria mellea was the primary cause of their death. No white oaks in this region were seen which had bcen struck by lightning; this was in marked contrast to the number of chestnut trees in the same territory which had been struck.

The only explanation which can be offered for the small percentage of young chestnut trees which had been killed by the root-rot is that the present stand of chestnuts originated mainly from sprouts, and the young trees therefore had the large root system of the parent stump from which to draw nourishment. As a result, their growth would be very vigorous during the first 10 or 15 years of life. Under such conditions one would not expect a hemiparasite like Armillaria mellea to attack them as readily as it did the suppressed young oaks. This, however, does not explain why the disease has killed so many of the older and larger chestnut trees, unless the old stumps acted as a breeding ground for the mycelium until it obtained a foothold in the living trees. The chestnuts undoubtedly were growing under unfavorable conditions, a fact proved by the very small annual increment. This would make them more subject to diseases of this type. The weather conditions in the past may have been such as to weaken the trees and thus make them more susceptible to this rot. For instance, in the year 1913 the chestnut trees had lost two sets of leaves from late frosts, and at the time this investigation was made (June $19,1913)$ the third set of leaves was not fully dereloped, and many of the trees were so badly injured that they apparently were not going to leaf out at all. 


\section{AREAS INFECTED BY ARMILLARIA MELLEA.}

Ten distinct badly diseased areas of varying sizes were found in which the Armillaria root-rot had killed many trees. On one area 40 yards in diameter, both chestnuts and oaks of large size had been killed, including 6 chestnuts with diameters of $8,8,10,12,14$, and 16 inches, and 4 oaks with diameters of $8,13,14$, and 14 inches, respectively. Another rather large area had 34 dead trees scattered over it; of these there were 25 white oaks, 6 chestnuts, and 3 poplars. These trees ranged from 3 inches to 26 inches in diameter. On none of these diseased areas were all of the trees killed; some were alive and apparently in good health. This root-rot apparently was much worse where the soil was very damp, or even wet, during certain portions of the year.

Mr. H. M. Sears, of the Forest Service, in a report entitled "Deterioration of Blight-Killed Chestnut in Northern New Jersey," mentions the presence of the rhizomorphs of Armillaria mellea beneath the bark of some of the dead chestnut trees. No evidence was advanced, however, to show that this fungus had attacked the chestnut trees before they died.

\section{ARMILLARIA MELLEA ON CHESTNUTS IN NORTH CAROLINA.}

AREA EXAMINED.

On a recent trip through North Carolina, the writer found a rhizomorphic root-rot prevalent on the chestnut near Mount Airy, N. C., which is apparently the same as that found in New York. As the investigations in North Carolina were devoted primarily to the heartrots of trees, very little time was given to this root-rot problem. However, some data on the character and extent of the disease were taken. The area studied was located about 6 miles east of Mount Airy, near Brim, N. C.

\section{CHARACTER AND GENERAL CONDITION OF THE TIMBER.}

The timber was located on the ridges and slopes and consisted of a mixed stand of chestnut and oak growing in a rather thin, more or less rocky soil with a red-clay subsoil. Chestnut oak (Quercus prinus) was the principal species of oak, but white oak $(Q$. alba), black oak (Q. velutina), and red oak (Q. rubra) were also present. All of the chestnut over the area examined was deteriorating, 90 per cent was stag headed and much was actually dying, while from 20 to 30 per cent was already dead. There was little or no sprout reproduction from the bases of the affected trees. Because of the rotted condition of the roots, the dead and dying trees in this region are easily blown down. According to resident millmen, this dying of the chestnut has become very pronounced during the last fifteen to twenty years. 
The chestnut orer this area originated mainly from seedlings, and, judging from the large annual increment, it made a healthy and vigorous growth before this trouble appeared.

\section{NUMBER AND CONDITION OF THE INDIVIDUAL TREES EXAMINED.}

The roots of 71 dead or badly diseased trees were examined. Of this number, 64 were chestnuts, 5 black oaks, 1 a chestnut oak, and 1 a sassafras. Of the chestnuts, 55 were already dead and 23 of them had been blown down when the studies were made. This afforded an opportunity to examine the condition of the roots. Nine of the living chestnuts studied were either dying or badly stag headed. Chestnut trees of all sizes were found dead or dying. Of the 64 chestnuts studied, 7 ranged in diameter from 4 to 10 inches, 23 from 11 to 20 inches, 29 from 21 to 30 inches, and 5 had diameters greater than 30 inches. An occasional black oak was found dead or badly stag headed, especially when adjacent to the worst affected chestnuts. The chestnut oaks, however, seemed to be vigorous and in the best of health. Especially raluable data were obtained from a windthrown chestnut 38 inches in diameter, which had been living but was badly stag headed when blown down. This tree was blown down only 11 days before the data were taken. The condition of its roots and stool was, therefore, exactly the same as when alive. When this tree was overthrown, several of the most superficial roots were still alive, but all of the deeper roots were dead. The sapwood of the dead roots was white rotted and corered with a network of black rhizomorphic strands. This rot was gradually encroaching on the living roots and killing them. The tree stood on the top of a rocky red-clay ridge, with the bulk of its roots within 2 feet of the surface of the soil.

All of the 71 trees examined had the "shoe strings" of Armillaria mellea on their roots. They were also found in a few instances extending from 3 to 8 feet upward beneath the bark on both living and dead trees. As a rule, however, the rhizomorphs were inconspicuous and were confined mainly to the roots and stools of the affected trees. The area studied was very limited, and no attempt was made to examine the roots of a large number of living trees. The data given here are therefore too meager to justify any positive opinion as to the amount of damage done by this root-rot in North Carolina. However, the prevalence and apparent destructiveness of this fungus over the area examined seem to point to it as very probably an important factor in the gradual recession of the chestnut in that State. If such an organism is at work, it would in a large measure explain the hitherto unexplained phenomena associated with this recession, such as the lack of reproduction from sprouts and the failure of the chestnut to reoccupy its former territory. A more extended investi- 
gation covering the entire range of this recession may or may not show the presence of this root-rot as abundantly over the other regions involved as it is at Brim. The identification of this rootrotting organism as it occurred both in New York and in North Carolina was made from the rhizomorphic strands present on the affected trees. No sporophores were found, as the time of the year during which the diseased trees were examined was not the proper season for their appearance.

\section{CONCLUSIONS.}

(1) The chestnut near New Berlin, N. Y., and at Brim, N. C., is deteriorating. This is clearly shown by the small annual increment during recent years, by the thin sapwood, by the large percentage of diseased and stag-headed tops, and by the number of dead and dying trees. This decline is probably due to several factors, one of which is the root-rotting fungus Armillaria mellea, but it should be noted that in spite of these facts the chestnut bark disease (Endothia parasitica) is not present in these localities.

(2) Armillaria mellea can become an active parasite under favorable conditions, especially in chestnuts and oaks, killing not only suppressed trees in the forest, but also those that are growing under more favorable environments.

(3) The prevalence and apparent destructiveness of this fungus over the area examined in North Carolina seem to point to it as very probably an important factor in the gradual recession of the chestnut in that State. 






